\title{
O processo enunciativo do texto literário dramático
}

\author{
The enunciating process of the dramaticliterary text \\ EDSON ROBERTO BOGAS GARCIA \\ EDUARDO CÉSAR CATANOZI \\ Centro Universitário de Votuporanga - Votuporanga - São Paulo - Brasil
}

-

\begin{abstract}
Resumo: Este artigo examina os mecanismos de enunciação do drama, uma vez que também na dramaturgia há uma voz reguladora do discurso, que conduz o sentido da obra. O enunciador do texto dramático aparece fragmentado, disperso em vários eus, escondido por entre o diálogo das personagens. Assim, a situação de enunciação, no texto de teatro, se diferencia da de outros tipos de narrativa, pois, nessa manifestação literária, normalmente não temos, como no conto ou romance, a figura de um narrador que se encarrega de direcionar o discurso. Esse processo enunciativo define a teatralidade de uma obra, separando o que é drama e o que é literatura com diálogos. A história contada no texto escrito de teatro, ou seja, a literatura dramática, deixa também ela entrever um ponto de vista, já que existe uma instância produtora do sentido.
\end{abstract}

Palavras-chave: Drama; Enunciação; Teatralidade; Ponto de vista

\begin{abstract}
This article examines the mechanisms of the enunciation of the drama, once that in dramaturgy there is also a discourse-regulating voice, which leads the meaning of such a work. The one who enunciates the dramatic text appears fragmented, spread into several 'I - individuals', hidden among the characters' dialogue. Thus, the situation of enunciation, in a theater text, differenciates itself from other types of narrative, because, for this literary manifestation, we usually don't have as, as in a short story or novel, the role of a narrator who is in charge of managing the discourse. That enunciating process defines the theatricalism of a work, setting apart 'what drama means' from 'what literature with dialogues means'. The history told in the written text of the theater, which stands for dramatic literature, it also lets itself foresee a point of view, once there is a productive request of meaning.
\end{abstract}

Keywords: The drama; Enunciation; Theatricalism; Point of view

\section{Introdução}

Quando se discute a dramaticidade na literatura, algumas questões devem ser debatidas, como os elementos definidores do drama, ou, até mesmo, se o texto dramático pode ser considerado gênero literário, uma vez que sua escrita pressupõe uma encenação. Caso seja literatura, como se dá o processo enunciativo? Como se define a teatralidade de uma obra? Há um direcionamento do ponto de vista no drama como existe em outras narrativas (pelo narrador) ou em textos poéticos (pelo eu-lírico)? $\mathrm{Na}$ busca de algumas respostas a essas perguntas, propomos algumas reflexões, que se esboçam neste artigo.

Normalmente, quando as pessoas analisam peças de teatro, preocupam-se em observar elementos cênicos como a composição cenográfica, figurinos, sonoplastia, estilo de interpretação e componentes textuais, os quais acabam sendo reduzidos à verificação da ação dramática, ou seja, ao desempenho actancial das personagens. O termo narração, no teatro, é evitado, já que se costuma considerar dramática a obra que põe em cena acontecimentos, fatos e peripécias sem a mediação de um narrador. Entretanto, nunca podemos nos esquecer de que teatro é discurso e, como tal, necessita de uma voz (ou vozes) organizadora(s), que tanto pode(m) estar explícita(s) - caso de peças em que uma personagem conta toda a história ao leitor/espectador - como oculta(s) nos diálogos e rubricas (indicações cênicas).

Essa voz que alinhava as falas das personagens, que leva a ação a se desenvolver e deixa algumas marcas da sua presença é a enunciação, que está subjacente em todo o texto. É a voz organizadora do discurso teatral, a qual maquia a artificialidade inerente ao jogo cênico, instaurando a ilusão, ou escancara o seu processo de 
construção, desvelando uma realidade representada, que pode ser assimilada pela recepção da obra.

\section{A natureza do texto dramático}

Antes de se fazer qualquer consideração sobre o texto dramático, é essencial que lhe compreendamos a natureza, para que possamos entender sua estrutura e função.

Muitos estudiosos, desde Aristóteles, concordam que o elemento caracterizador do texto teatral é a ação, pois, quando encenamos uma peça, não narramos uma história, mas estamos mostrando-a ao público, que tem a impressão de vê-la hic et nunc, ou seja, no momento de sua ocorrência. Mesmo quando a ação acontece em flashback, quando uma personagem no presente rememora seu passado, a ação pretérita é revivida pela lembrança, que a presentifica. Daí o motivo da abundância, no texto teatral, de dêiticos do tipo "aqui", "agora", "aí", "isto", "aquilo lá", "ontem", já que, como não há a presença do narrador (como entidade bem marcada), a indicação espacial e temporal deve ser clara. No teatro, falar é mostrar, pois se a personagem diz, por exemplo, "aqui, neste jardim", a cenografia deve conter folhas e flores, ou, na ausência delas, o encenador deve instigar a imaginação do espectador a visualizá-las.

E quando as personagens têm a função de estar em cena sem fazer nada, sem executar nenhum movimento, apenas "recitando" o seu texto, ainda temos ação, pois falar é agir. No palco, a simples presença de uma personagem inerte, que nada diz e não se desloca, é significativa, pois, nesse caso, ficar parado possibilita uma leitura ao espectador.

Pallotini (1988, p. 6-7), debate a ação como a única definidora da natureza teatral, pois se essa fosse responsável exclusiva pela definição do drama, enquanto almoçamos, na vida real, estaríamos fazendo teatro, uma vez que estamos agindo. A autora resgata, então, o pensamento de Hegel, para quem a ação só tem sentido se por trás dela houver um conflito que progrida dramaticamente durante o espetáculo.

Dessa maneira, é falha a noção que algumas pessoas têm de que basta o diálogo para um texto ser teatral, pois, se assim fosse, todas as narrativas que abusassem do discurso direto seriam textos dramáticos.

Em sua pesquisa sobre a dramaturgia, Pallotini (1988) realiza um levantamento das definições do texto de teatro segundo diversos autores, estudo que sintetizamos no Quadro 1.

Diante de tantas tentativas de se apreender a natureza do gênero dramático, definindo-o como ação, conflito, crise, emoção, podemos chegar à conclusão deque esses elementos não se excluem, mas se somam e
Quadro 1. Definições do texto de teatro segundo diversos autores.

\begin{tabular}{|l|l|}
\hline Ferdinand Brunetière & $\begin{array}{l}\text { o que caracteriza o texto dramático é o } \\
\text { exercício de uma vontade. }\end{array}$ \\
\hline William Archer & $\begin{array}{l}\text { para que haja dramaturgia é necessário } \\
\text { crise. }\end{array}$ \\
\hline Henry A. Jones & $\begin{array}{l}\text { um texto de teatro deve conter uma } \\
\text { sucessão de suspenses e crises, ou seja, } \\
\text { vários conflitos iminentes e deflagrados. }\end{array}$ \\
\hline George Pierce Baker & $\begin{array}{l}\text { teatro é emoção, que advém da ação } \\
\text { dramática. }\end{array}$ \\
\hline Lawson & $\begin{array}{l}\text { o conflito dramático deve ser um conflito } \\
\text { social. }\end{array}$ \\
\hline
\end{tabular}

Fonte: PALLOTINI, 1988.

ganham destaque em épocas diferentes de acordo com a estética em vigor. Assim, para o teatro clássico, para que houvesse dramaturgia eram necessárias as três regras da unidade - tempo, espaço e ação -, ao passo que o teatro melodramático se apoiava na emoção, a qual, por sua vez, era minimizada no distanciamento do teatro de Brecht.

Apesar da grande diversidade dos espetáculos encenados - alguns verborrágicos, outros sem texto (apenas com roteiro), musicais, realistas, absurdos raramente questionamos estar ou não diante de uma obra de teatro, pois acreditamos que, por trás dos elementos definidores da natureza teatral, encontra-se a enunciação, regendo e colocando em funcionamento, de maneira peculiar, todos os componentes do texto dramático.

\section{O texto dramático: arte para ser lida ou encenada?}

As rubricas, ou informações cênicas observadas nos textos de teatro são direcionadas ao leitor que inicia a obra literária ou aos encenadores, que têm a tarefa de mostrar o espetáculo ao público? Sob esse tipo de indagação esconde-se um questionamento ainda maior, que coloca em dúvida a inclusão do texto dramático em compêndios de literatura, já que a obra poderia existir apenas para as pessoas interessadas em encená-la.

Quando lemos um texto poético, além do sentido geral que captamos racional e emocionalmente, há o prazer de percorrer os olhos pelos versos, sensação explorada com maior intensidade pelos concretistas e que nos impele a compor imaginariamente um quadro ou uma história. Da mesma forma, a obra em prosa nos permite imaginar, por exemplo, cenários, figurinos, sons e cheiros. Constituem prazeres distintos a leitura com os próprios olhos (ou mãos, no caso da escrita em braile) e a oralização do texto, que nos faz atentar para o som das palavras, para a intenção, cromatismo, tom, altura da voz, para o silêncio ou pausa. Segundo Bajard (1999), 
ler, oralizar e dizer são atos distintos, uma vez que a leitura silenciosa tem como finalidade a elaboração de um sentido e a transposição oral é uma prática vocal e social do texto, cujo objetivo é a comunicação. $\mathrm{O}$ autor condena a expressão "ler em voz alta", preferindo utilizar o termo "dizer, para a atividade de comunicação vocal de um texto preexistente", e "oralizar, para a atividade de identificação das palavras através da voz" (BAJARD, 1999, p. 74)

Ora, se existe essa dupla especificidade - o texto pode ser lido ou ouvido - e se mesmo poemas e romances despertam a visualização imaginária de imagens, por que o texto dramático teria apenas a função da encenação?

Quando o dramaturgo redige seu texto, antes de se dirigir ao público, tem a missão de comunicar-se com o leitor da obra escrita, o qual deve apreender, integralmente, o sentido do espetáculo virtual que se lhe desenha, já que, mesmo para os encenadores, o primeiro contato com a obra teatral se dá por meio do texto linguístico.

As indicações cênicas seriam, então, caracterizadoras do drama? Não, já que peças nem sempre têm informações explícitas sobre a encenação, o que abre uma maior probabilidade de leitores diferentes conceberem uma mesma cena de modos distintos. Isso não quer dizer que o leitor comum, que não tem intenção alguma de realizar a encenação no palco, não constrói, virtualmente, a cena que lê: ele apenas possui uma sinalização menor do que o leitor de uma obra com informações abundantes nas indicações cênicas.

Constata-se, portanto, que o dramaturgo deve dirigirse tanto ao leitor da obra impressa quanto ao espectador e ambos os destinadores devem ser capazes de sentir-se satisfeitos diante da obra enunciada, o que não quer dizer que se trata de artes autônomas, pois a peça de teatro possui como destino virtual sua encenação: o leitor do texto escrito imagina-se espectador da cena. Da mesma forma, o texto de teatro não pode ser classificado, sozinho, como "a obra teatral", já que é mais um dos constituintes dessa arte tão plural, ou seja, que abraça tantas outras, como a literatura, a música e a dança.

Quando se assiste ao espetáculo, a obra escrita salta do papel e ganha nova existência no palco, convertendose em oral, visual, auditiva e, até mesmo, olfativa, uma vez que as indicações cênicas, como não são lidas, devem ser captadas pelo público.

Se a base de uma montagem teatral é o texto, que por sua vez é a primeira forma de existir das personagens e do enredo e que deve conter as informações necessárias para a transposição para a cena, poderia o teatro tomar forma sem que a representação cênica esteja apoiada no texto verbal? Alguns artistas, acreditando no divórcio que pode ocorrer entre a expressão linguística e a visual, acusam de autoritário o texto dramático, pois ditaria ao encenador e ao ator uma cena pronta, amarrando-os em uma camisa de força que os impediria de exercitar sua liberdade de criação e de imaginação. Essa linha de pensamento inauguraria, para esses artistas, um teatro forro, não-ancorado no texto verbal e que permitiria uma existência independente para a ação dramática, sem os ditames da palavra.

Não desconsiderando a boa intenção de buscar novas maneiras de expressão, esse tipo de espetáculo é apenas uma miragem de rompimento com a obra linguística, pois o que pode ocorrer, por exemplo, é o texto escrito estar disfarçado de roteiro, o que assim mesmo constitui dramaturgia. Mesmo nas peças em que se improvisa, há uma base sobre a qual os autores criam. No teatro de imagens, em que não se profere palavra, o texto verbal é convertido em outros tipos de linguagem, mas, uma vez posto em cena, tem de ser dramático.

Os jogos de improvisação, às vezes, permitem que o ator entre no espaço cênico sem um texto prévio e que o público, ou outro estímulo exterior, lhe dê o mote para o desenvolvimento do espetáculo. Mesmo nesse caso há uma dramaturgia, que supôs que isso aconteceria e que permitiu que a ação dramática se desenvolvesse no momento da encenação no palco.

Ora, se a arte teatral está tão alicerçada na dramaturgia e se ambas, a cena escrita e a sua encenação, podem existir separadamente, mesmo que uma pressuponha a outra, por que, no Brasil, os leitores praticamente não procuram peças de teatro?

Se a circulação e leitura de boas obras literárias, em prosa ou verso, são preocupantes, o texto de teatro é, praticamente, esquecido, talvez pelo preconceito ainda vigente de que a obra dramática deve ser lida apenas pelas pessoas que trabalham com teatro.

Outro problema é o da edição de bons textos de teatro, que, mesmo quando publicados, recebem divulgação irregular. Algumas peças possuem apenas cópias caseiras que circulam entre os artistas e em alguns (poucos) bancos de textos dessa natureza. Outras, de dramaturgos consagrados, como Nelson Rodrigues, Oswald de Andrade, Jorge Andrade, Plínio Marcos, dentre outros, gozam de boas edições, mas não conseguem difusão significativa, apesar dos esforços de alguns autores e editores.

Paradoxal é a situação de alguns novos autores de teatro, que não têm suas obras encenadas por falta de edição - não as encontramos em livrarias - e não têm seus textos editados porque ainda não ganharam encenação. Dessa maneira, o teatro, que tanto pode ser lido quanto encenado, não sobrevive de maneira nenhuma. $\mathrm{O}$ contato com a obra no papel poderia despertar a curiosidade de vê-la no palco e, da mesma forma, o espectador ficaria motivado a ler um texto dramático depois de ver sua 
representação, e, assim, a literatura dramática cumpriria sua dupla função: arte para ser lida e encenada.

\section{Enunciação e teatralidade}

Se afirmamos que a obra teatral existe para ser lida e encenada, podemos dizer que tudo o que lemos pode ser representado no palco?

A reflexão sobre esse assunto nos leva a questionar o que estaria definindo a teatralidade de uma obra, já que a simples presença de diálogos não a caracteriza como teatral. Há textos em que predomina o discurso direto, mas, nem por isso, podem ser considerados adequados para encenação. Por outro lado, há aqueles que, apesar de não apresentarem a forma dialogada, na transposição para a cena, nada devem a obras escritas originalmente como drama. Aliás, nos últimos anos, temos assistido a um alargamento das possibilidades teatrais, em que se veem textos de naturezas diversas, sobretudo de cânones dos textos narrativos e poéticos serem transformados em espetáculos.

Quando, por exemplo, uma passagem bíblica, um romance, um poema, são encenados, há uma recodificação para a linguagem cênica, ou seja, a obra original serve como mote para o dramaturgo e/ou encenador, aos quais cabe realizar a recriação para a linguagem do teatro, isso porque a enunciação teatral não se realiza da mesma maneira em outras manifestações artísticas e é ela que as diferencia.

Já que a matéria-prima do teatro pode ser encontrada em instâncias diversas, podemos entender como teatral toda narrativa que possua personagens agindo ou refletindo sobre determinado assunto e que apresente tema e conteúdo adequados para serem mostrados em cena.

Entretanto, não se pode reduzir a teatralidade ao plano de conteúdo de uma trama, pois isso não basta para que determinada história seja encenada. Por mais que consideremos teatral, por exemplo, um romance, sua enunciação não foi realizada para a cena. Dessa forma, a obra não-dramática pode não resultar em bom teatro se não passar por nova enunciação escrita, ou seja, se não for adaptada para a dramaturgia, ou por nova enunciação cênica, em que o texto verbal pode ser mantido, acrescentando-se a ele os elementos do espetáculo.

Pavis (1999, p. 372) deixa transparecer visão semelhante quando afirma que: $\mathrm{O}$ teatro é mesmo, na verdade, um ponto de vista sobre um acontecimento: um olhar, um ângulo de visão e raios ópticos o constituem. Tão-somente pelo deslocamento da relação entre olhar e objeto olhado é que ocorre a construção onde tem lugar a representação.

Esse "ângulo de visão" diz respeito à forma como os produtores do discurso dramático fazem enunciar a peça, ou seja, um acontecimento, por si, não é teatral, mas pode vir a sê-lo após um processo dramatúrgico. Chegamos, com isso, a uma definição de teatralidade: são teatrais temas e conteúdos que têm uma carga de dramaticidade e que podem ser, de alguma maneira, levados à cena. Essa teatralidade pode ser menos ou mais visível ao leitor, dependendo da existência de indicações para a encenação no texto considerado como fonte.

Então, tudo é teatral? Ora, uma vez que o palco é o espaço em que se permite recriar a realidade objetiva e dar forma ao universo onírico, nenhum tema pode lhe ser estranho, estando subordinado, apenas, aos recursos teatrais de que se vale para realizar a consubstanciação em cena. Uma obra é considerada, por isso, menos ou mais teatral se estiver apoiada em conjunto menor ou maior dessas técnicas para ser transposta para o espaço cênico.

No ato da representação, essa teatralidade do texto pode ser ou não apagada pelo encenador e pelo ator, aos quais é facultada a opção por uma interpretação mais naturalista, em que não se desvenda ao público a embreagem dos elementos constitutivos do teatro, imprimindo à cena um grau maior de ilusão.

Quando o texto evoca uma interpretação mais contida do ator, porquanto o universo recriado em cena busca retratar mimeticamente alguns aspectos do mundo extra-ficcional, não significa que a peça seja pouco teatral, conforme a confusão que algumas pessoas fazem com o termo, emprestando-lhe sentido de grandiloquente e afetado. É teatral, como dissemos, pela maneira como a enunciação é conduzida e, uma vez que a teatralidade está ligada diretamente à enunciação de uma obra dramática, é ela quem vai distinguir um texto de teatro de qualquer outro, ao definir sua natureza.

\section{A enunciação do texto dramático}

Diferentemente do romance, não existe, na obra de teatro, um narrador explícito que se encarregue de contar a história, salvo algumas exceções, quando cabe a uma personagem - denominada ou não narrador - dirigir-se ao leitor/espectador para comentar sobre os acontecimentos.

É comum a explicação de que inexiste uma instância narrativa que conduz a ação dramática, como se, subjacente aos diálogos, houvesse apenas a intenção comunicativa das personagens. Quando se tem essa crença, o teatro convencional atinge o grau máximo da ilusão, pois consegue tornar verossímil o seu jogo de mentiras e verdades. Entretanto, não se pode esquecer que, por trás de toda obra de arte, existe uma elaboração cuidadosa por parte da emissão, que organiza os signos em um todo expressivo.

O esquema do processo da comunicação proposto por Roman Jakobson (1969) nos mostra que seis componentes 
se engendram na produção de enunciados: um emissor dirige sua mensagem a um receptor por meio de um canal, utilizando-se de um código em determinado contexto. Se nos basearmos nesse esquema e o aplicarmos ao discurso teatral, observaremos a plissagem dos elementos do processo, já que em uma mesma cena podemos construir diferentes esquemas:

\section{Esquema 1:}

- Emissor o autor.

- Receptor o leitor da peça.

- Mensagem a peça.

- Canal a língua escrita.

- Código a língua em que a peça foi escrita.

- Contexto leitura de uma peça teatral.

\section{Esquema 2:}

- Emissor o autor e a companhia teatral.

- Receptor o público.

- Mensagem a peça encenada.

- Canal as personagens/atores, os refletores, os figurinos, a maquiagem, entre outros.

- Código a linguagem do teatro.

- Contexto encenação de peça teatral.

\section{Esquema 3:}

- Emissor uma personagem.

- Receptor outra personagem.

- Mensagem o texto que está sendo proferido.

- Canal a fala, os gestos, entre outros.

- Código linguagem oral, linguagem gestual, etc.

- Contexto a situação de que a peça trata.

Percebe-se, então, que temos um emissor 1, que é o autor; um emissor 2, que é a companhia teatral; e um emissor 3, que é a personagem que fala. $\mathrm{O}$ emissor 2, a companhia teatral, pode ser desdobrado, pois há os atores, o diretor, os iluminadores, maquiadores, sonoplastas, entre outros. Em contrapartida, observamos um receptor 1, que é o leitor da peça; um receptor 2, que é o público que assiste ao espetáculo; e um receptor 3, que são as personagens que recebem a mensagem.

Mainguenau (1996, p. 159), ao se referir à enunciação teatral, observa uma dupla situação:

- na primeira, um autor se dirige a um público através da representação que constitui o ato da enunciação;

- na segunda, a situação representada, personagens trocam frases num contexto enunciativo supostamente autônomo com relação à representação.

Ao utilizar os termos "representação" e "situação representada", Mainguenau (1996) mostra uma dupla articulação da linguagem teatral, que dá voz a duas categorias distintas: autoria e personagens.

Tomando-se por base essas observações, poderíamos afirmar, então, que existe o que denominaremos de enunciação das figuras dramáticas, que seria a troca conversacional entre enunciadores, ou seja, o diálogo que uma personagem mantém com outra, e a enunciação conjunta do texto dramático, que se preocupa com o que Fiorin (1996, p. 31), chama de "ato produtor do enunciado".

Dessa forma, se por um lado a análise da enunciação de uma peça de teatro pode verificar, por exemplo, as diferenças do discurso das personagens, revelando sua cosmovisão, por outro, pode exibir, nos interstícios do diálogo, determinado posicionamento do enunciador que, por exemplo, organiza as cenas, seleciona palavras e o modo de pronunciá-las.

Constatada essa duplicidade no discurso teatral, Mainguenau (1996, p. 160) sente falta de uma nomenclatura para o que nós chamamos de enunciação conjunta do texto dramático e encontra, em Michael Issacharoff, uma definição que passa a adotar: "No teatro, estamos diante de interlocutores aparentemente autônomos, mas cujo conjunto de enunciados, a peça, está relacionada a uma fonte enunciativa invisível que, com M. Issacharoff, seria possível chamar de arquienunciador".

Parece-nos que o termo "arquienunciação" não é de todo adequado, uma vez que o prefixo, do latim archi ou do grego arkhi, carrega a ideia de preeminência, superioridade e, portanto, a noção de escalonamento de importância, como se o enunciador do texto estivesse acima dos outros, o que não acontece, pois, no teatro, temos um coral de enunciadores que, quando em harmonia, fazem soar a música do espetáculo. A polifonia do discurso teatral exige o trabalho em equipe de vários enunciadores - autores, atores, diretores, maquiadores, iluminadores, cenógrafos -, cujo conjunto forma a enunciação do espetáculo.

Mesmo que Mainguenau e Issacharoff estejam se referindo apenas ao texto escrito, ainda assim acreditamos que o termo é impreciso, pois, conforme o próprio Mainguenau (1996, p. 166), "também num romance parece que se está diante de dois destinatários: o interlocutor imediato e o leitor". Se, no romance, temos 1) as personagens, que, como no teatro, enunciam determinada fala em discurso direto, 2) um narrador que dirige o foco de visão do leitor e 3 ) um enunciador que se insinua em todo o discurso, então para que criar, no teatro, o termo arquienunciador?

No texto dramático não encontramos, salvo algumas exceções, a figura do narrador, o que talvez tenha motivado essa necessidade de criação de terminologia distinta do romance. Embora nem sempre exista, no teatro, a explicitação de personagem que exerce a função de intermediária entre a ação da peça e o público, há uma voz condutora que permite determinado tipo de focalização dramática. Nesse sentido, o enunciador 
possui função semelhante à dos atores em um espetáculo de bonecos, que, durante a manipulação, emprestam suas vozes aos fantoches; e o público, mesmo sabendo da animação por meio de efeitos teatrais, deixa-se acreditar na ilusão proposta pelo jogo. Assim, há uma enunciação em palimpsesto, em que enunciadores (as personagens) dublam a voz de um enunciador que organiza todo o discurso. Por sua vez, quando o texto escrito ganha o palco, há um novo decalque, pois os atores abraçam as personagens, emprestando-lhes, por exemplo, corpo e fala, e direção e equipe técnica sorvem a enunciação do texto para, com base nela, compor a sua.

Claro está então que todo o processo da enunciação teatral nasce no momento em que o dramaturgo enuncia seu discurso e se instaura, de acordo com nossa visão, não o arquienunciador, mas o que chamaremos de enunciadorfonte.

Uma vez que, no teatro, os diálogos não são, normalmente, mediados por um narrador, as informações têm de ser transmitidas ao leitor de formas diferentes. Ryngaert (1995, p. 117) elenca algumas possibilidades:

A informação pode ser:

Abundante: a fala das personagens fornece informações exaustivas sobre sua citação, seu estado civil, seu passado, suas esperanças, suas relações com as outras personagens.

Rara: nenhuma dessas informações é dada, e o diálogo funciona segundo um implícito tão intenso entre as personagens que toma o aspecto de uma conversa privada da qual o leitor é como que excluído.

Direta: as informações são fornecidas pelo que elas são, sem que o autor procure dissimular seu caráter de mensagem destinada ao leitor ou ao espectador. Elas podem assumir a forma de monólogos ou de comunicados.

Indireta: através dos meandros dos discursos, compete ao leitor ou ao espectador formar uma opinião sobre o grau de utilidade das informações que lhe são fornecidas.

Pode-se também dizer que a informação é pública (dada como tal) ou discreta (toma o aspecto de uma "verdadeira conversação"); que ela é maciça (identificam-se "blocos informativos") ou difusa (difundida em todo o texto sem que momentos particulares sejam privilegiados do ponto de vista da informação).

Combinações são possíveis: a informação pode ser abundante e discreta, ou abundante e direta, e assim por diante, conforme as dramaturgias.

Além dessas informações distribuídas nos diálogos, as rubricas (indicações cênicas) e a linguagem não-verbal complementam as informações que não foram expostas ou insinuadas nas falas das personagens.

\section{O ponto de vista no drama}

Uma vez que, na dramaturgia, como em qualquer outro gênero, há uma ideologia implícita, faz-se necessário analisar a questão do ponto de vista na obra dramática.

Se no teatro as personagens não são introduzidas por narrador, mas há, como vimos, na obra escrita, um enunciador que organiza os diálogos, existe uma focalização mais abrangente do texto ou apenas o ponto de vista de cada personagem?

Se há, tanto no romance como no teatro, instâncias produtoras do sentido, existe, consequentemente, um ponto de vista eleito, pois, diferentemente da espontaneidade do diálogo cotidiano, as falas no teatro são controladas por um demiurgo repleto de intencionalidade.

Poucos são os estudos do ponto de vista no texto dramático, entre eles, o de Barko e Burgess (1988, p. 5), para os quais

[...] au concept de point de vuedans le domaine théâtral sera nécessairement métaphorique, commeil'est d'ailleurs dans le domaine du roman: seul le cinéma est capable l'adopter un point de vue proprement dit, un point de vue ausens concret du mot, permettant la rencontre, voire la coïncidence, de l'angle de vision de la caméra en tant que l'oeil du cinéaste-auteur et son angle de vision en tant que l'oeil du spectateur.

Como se nota, para Barko e Burgess (1988), o ponto de vista é mais facilmente observável no cinema, pois há coincidência do olhar do diretor, que direciona a câmera para determinado ponto (de um ângulo específico), com o olhar do espectador, que, necessariamente, observará o que as lentes captaram. No teatro, se pensamos na enunciação do espetáculo, o diretor, atores, iluminadores e outros profissionais podem também direcionar o olhar do espectador para o que desejam por meio de algumas técnicas, como:

- recorte de luz: há uma maior incidência de iluminação sob o ponto que se quer destacar.

- gestualidade do ator: um gesto ou um olhar podem direcionar a atenção da plateia para onde o diretor e/ou o ator desejarem.

- marcação cênica: a posição definida de um objeto e de um ator em cena pode conferir-lhes maior ou menor ênfase.

- inflexão, ritmo e volume de voz: a maneira como se pronuncia uma frase é significativa para realçar o que se deseja. Da mesma maneira, o silêncio (as chamadas pausa ou pausa de tensão) podem atrair a atenção do espectador.

- inclusão de sonoplastia: o som bem escolhido pode destacar momentos do espetáculo. 
- características de cenário, figurino e maquiagem: esses elementos plásticos podem sublinhar uma personagem em especial, uma característica sua ou um lugar no palco.

Todas essas técnicas se amalgamam para construírem, juntas, o sentido doespetáculo que ora deseja evidenciar uma característica, ora apagá-la, como bem lembra Patrice Pavis: "Evidenciar não é senão encenar de modo 'equilibrado': pouca evidência não desemboca em nenhuma concepção organizada; evidência demais enfraquece o espetáculo e o banaliza, por falta de ambiguidade suficiente" (1999, p.120)

Quando se relaciona o ponto de vista à câmera de cinema ou aos recursos técnicos da encenação, não se leva em conta que o roteiro cinematográfico e o texto dramático apresentam também ponto de vista que deve nortear a enunciação cênica. Dessa maneira, os recursos imagéticos que elencamos são absorvidos da obra escrita, a qual se vale de suas próprias técnicas para apresentar as ações sob uma perspectiva definida.

Para analisar o ponto de vista no texto dramático, Barko e Burgess agruparam cinco fatores que determinam a distância estética:

- fatores cênicos.

- fatores cognitivos.

- grau de focalização interna.

- coerência das personagens.

- fatores afetivos e afinidades ideológicas, morais, sociais, etc.

\subsection{Fatores cênicos}

Por fatores cênicos, Barko e Burgess (1988, p.18) entendem as exigências da intriga, a presença ou a ausência da personagem na cena, suas entradas e saídas, a importância quantitativa de um papel, as rubricas e outros fatores relevantes dos cânones ou convenções do gênero.

Os fatores cênicos, no seu conjunto, delimitam o ponto de vista da intriga e a importância de uma personagem na ação dramática. Para isso, Barko e Burgess propõem, ainda, a análise das funções dramáticas de Etienne Souriau(1993), para que todas as forças do texto possam ser mapeadas.

\subsection{Fatores cognitivos}

Os fatores cognitivos definem a distância que há entre o saber de uma personagem e o saber do espectador, pois se um actante partilha uma informação com a plateia, instaura-se entre eles uma situação de certa cumplicidade ou conivência; por outro lado, toda lacuna de informação tende a aumentar a distância.

Os fatores cognitivos de Barko e Burgess se relacionam com o que, em teoria da narrativa, chama-se de onisciência, a qual determina o que o narrador conta ou não para o leitor e para a qual Norman Friedman (1967), pesquisador do ponto de vista na ficção, fixou a seguinte classificação:

1. onisciência interpretativa ou intrusa: o narrador tem total liberdade para passear no interior das personagens, podendo, igualmente, criticar seus relatos. Dessa maneira, a história pode ser vista de vários ângulos e o narrador avalia e interpreta tudo o que descreve.

2. onisciência neutra: mais impessoal e objetiva que a primeira, nela o narrador restringe-se, tanto quanto possível, a contar os fatos.

3. "eu" testemunha: a história é narrada sob o ponto de vista de uma personagem que, em maior ou menor grau, participa na história. Tudo o que o narrador-personagem ouve, vê ou pensa é transmitido ao leitor.

4. "eu" protagonista: a personagem central narra a história sob o seu ponto de vista o qual é, praticamente, limitado às suas impressões.

5. onisciência multi-seletiva: não há um narrador direcionando o ponto de vista e cada personagem passa a registrar suas impressões.

6. onisciência seletiva: também não há um narrador conduzindo o ponto de vista, mas a visão do leitor é limitada à mente de uma das personagens.

7. modo dramático: não há mediação de um narrador e as falas das personagens são transcritas de maneira direta. As poucas indicações se assemelham muito às didascálias do texto de teatro.

8. câmera: não haveria marca de nenhuma instância na narração, nem do narrador, nem do autor e, aí, Friedman questiona essa ausência de uma voz organizadora da narração, pois um texto não se escreve sozinho.

Se, no texto dramático, Barko e Burgess, ao tratar dos fatores cognitivos, mostram a distância entre o saber da personagem e o da plateia, e Friedman trata da onisciência na narrativa, mostrando, justamente, por que o leitor tem uma visão mais geral ou restrita da história, perguntamonos por que não observar a fábula teatral pelo viés da onisciência.

Talvez não sejam habituais estudos dessa natureza devido à crença de que o drama, como simulacro da vida cotidiana, não necessita de voz mediadora (mesmo que inaudível). Na própria classificação da onisciência por Friedman podemos constatar que, ao enumerar o que ele chama de modo dramático, desconsidera que pode haver um texto de teatro, por exemplo, com onisciência intrusa, neutra, etc.

Assim, partindo da teoria de Friedman, tentaremos mostrar como, no teatro, a observação da onisciência 
é possível. Para isso, valer-nos-emos de classificação semelhante à que ele atribuiu à narrativa e faremos uma adaptação (nossa) para o drama:

1. onisciência interpretativa ou intrusa: todas as personagens têm liberdade para se dirigir à plateia, direta ou indiretamente, para deixar claro o seu ponto de vista sobre os fatos, motivo pelo qual o espectador tem uma visão bastante ampla, o que, entretanto, não impede que a enunciação direcione o posicionamento do leitor/espectador.

2. onisciência neutra: a ação se desenvolve em cena, mas as personagens não explicitam o seu ponto de vista, ou seja, evita-se a emissão de juízo de valor.

3. "eu" testemunha: os acontecimentos são mostrados sob a perspectiva de uma personagem, isto é, há coincidência do saber dela com o da plateia. Note-se que o ponto de vista pode não ser o do protagonista, mas o de uma outra personagem que acompanha os fatos.

4. "eu" protagonista: a história transcorre segundo a visão do protagonista, que divide seu conhecimento e impressões com o leitor/espectador. Essa técnica é bastante utilizada nos monólogos.

5. narrador personagem: há, na peça, uma personagem que não participa da ação, mas que fica à margem da história fornecendo algumas informações ao leitor/espectador. Pode, ainda, figurar na lista de personagens como narrador ou condutor.

6. narrador coro: um conjunto de atores tem a responsabilidade de narrar e comentar as ações e nelas intervir com ponderações e conselhos, direcionando o ponto de vista. $\mathrm{O}$ coro do teatro moderno não é exatamente igual ao do teatro clássico, pois pode aparecer transfigurado em personagens.

7. onisciência metalinguística: rompe-se a ilusão teatral $\mathrm{e} \mathrm{o}$ ator dirige-se à platéia para comentar ou narrar as ações das personagens.

Acreditamos que essas maneiras de dividir o saber com o leitor/espectador não são excludentes, já que um mesmo espetáculo pode combinar diferentes recursos. Percebe-se, com isso, que a questão do ponto de vista no drama é bastante complexa, pois há uma perspectiva da peça como um todo, das cenas isoladamente e de cada personagem.

Barko e Burgess (1988, p. 20) lembram que, em razão dos fatores cognitivos, uma personagem pode despertar simpatia ou piedade, o que pode compensar os erros cometidos por ela. Preferimos, no entanto, não nos aprofundar nesse mérito, por considerá-lo subjetivo demais: por diferentes motivos, uma personagem pode ser simpática para algumas pessoas e despertar a repulsa de outras.

\subsection{Grau de focalização interna}

Ainda segundo Barko e Burgess (1988, p. 20), enquanto os fatores cênicos analisam a personagem de fora, ou seja, suas ações, a focalização interna se ocupa de uma perspectiva interior, o que não implica, necessariamente, a identificação do público. O desnudamento do interior de uma personagem não se dá exclusivamente por meio do monólogo, mas também nos meandros dos diálogos, que, não podemos nos esquecer, são montados dramaticamente para que o leitor/espectador apreenda todas as informações de que necessita sobre a peça.

A focalização interna, de acordo com Barko e Burgess, "plus on nous laisse pénétrer profondément dans la vie intérieure d'un personnage" (1988, p. 20).

\subsection{A coerência das personagens}

A coerência das personagens diz respeito à embreagem entre o que se diz e o que se faz, pois não se pode levar em conta, na análise de um espetáculo, apenas o diálogo, mas também as ações efetivas dos actantes.

Barko e Burgess $(1988$, p. 21) propõem que se examine a concordância entre:

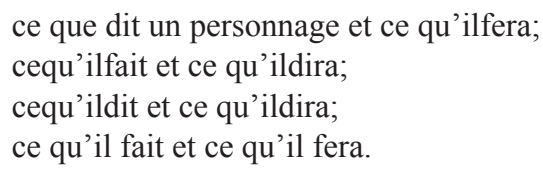

Observemos que os autores propõem que se verifique, além das palavras e das ações efetivas, a coerência entre tudo o que a personagem diz, ou seja, se ela entra em contradição, muda de opinião ou dissimula algo, e o que ela faz, pois durante o espetáculo pode haver uma mudança de conduta. Esse tipo de estudo permite a constatação da presença ou ausência, na trama, de índices e de falsos índices, ou seja, o leitor/espectador deve estar atento à concordância entre as ideias professadas por uma personagem e suas ações, o que pode variar a distância entre ambos.

\subsection{Fatores afetivos e afinidades ideológicas, morais, sociais, etc.}

O quinto fator que, segundo Barko e Burgess, influencia a distância entre o espectador e a personagem instala-se no âmbito dos valores, pois o espectador pode aprovar ou desaprovar as opiniões, os julgamentos e qualidades morais apresentadas no palco. Para os autores, tais fatores afetivos não têm, exclusivamente, origem moral: podem advir das características físicas de uma personagem, do modo de se vestir ou do seu comportamento. 
Os cinco fatores de Barko e Burgess, no seu conjunto, ajudam-nos a analisar o ponto de vista no drama, provando que, sob os diálogos de uma peça teatral, há uma intenção comunicativa que dirige ou tenta dirigir (consciente ou inconscientemente) a opinião do leitor/espectador sobre a ação dramática. O mérito da proposta de Barko e Burgess deve-se ao fato de que, em seu modelo de análise, privilegiam tanto o esquema actancial quanto se detêm em considerações mais detalhadas sobre as personagens e sua ideologia.

\section{Conclusão}

Neste artigo, pudemos constatar que, uma vez definidas a teatralidade de um texto, sua natureza e sua dupla função, ou seja, arte para ser lida e/ou encenada, o artista de teatro ou o leitor que não tem a intenção de encenar a peça podem entender melhor a obra que está diante deles, já que desvendam o processo de construção do drama. Comprovamos que a obra dramática escrita não se limita a uma sequência de diálogos, mas forma um conjunto coeso, repleto de intenção comunicativa, organizado por um enunciador, ao qual chamamos de enunciador-fonte. O texto impresso é, portanto, o espetáculo virtual e, consequentemente, a pedra angular das encenações que poderá (ou não) receber.

$\mathrm{O}$ entendimento da enunciação do texto permite ao leitor/espectador aprofundar-se no sentido geral da peça, na medida em que explicita valores implícitos da obra ou ratifica o que é percebido em uma primeira leitura. Por esse motivo, é do trabalho do dramaturgo que brota o papel do encenador, pois os responsáveis pela encenação devem ir ao encontro do enunciador da obra escrita a fim de compreender o significado global do espetáculo que desejam mostrar em cena. Não queremos, com isso, afirmar que o texto de teatro não pode, em hipótese alguma, receber um novo componente, ou seja, uma nova leitura, mas deixar claro que a transgressão do conteúdo de uma peça deve ser realizada após conhecimento aprofundado de sua intenção comunicativa, para que o adaptador tenha consciência de todas as mudanças realizadas. Se por um lado isso possibilita montagens bastante distintas de uma mesma obra, que tem, nas diversas leituras, uma ou outra característica reforçada, por outro pode, se o encenador não respeitar a proposta do enunciador do texto escrito, instaurar um duelo entre a obra impressa (lida) e a representada (assistida), como se o ventríloquo estivesse pronunciando algo enquanto o boneco permanece sem mover a boca.

\section{Referências}

BAJARD, Elias. Ler e dizer: compreensão e comunicação do texto escrito. São Paulo: Cortez, 1999.

BARKO, Ivan; BURGESS, Bruce. La dynamique des points de vue dans le texte de théâtre. Paris: Lettres Modernes/Minard, 1988.

BUARQUE, Chico; PONTES, Paulo. Gota d'água. Rio de Janeiro: Civilização Brasileira, 1981.

FIORIN, José. Luiz. As astúcias da enunciação: as categorias de pessoa, espaço e tempo. São Paulo: Ática, 1996.

FRIEDMAN, Norman. Point of view in fiction: the development of a critical concept. In: STEVICK, Philip (Ed.) The theory of novel. New York: Free Press, 1967, p. 198-137.

JAKOBSON, Roman. Lingüística e comunicação. Tradução Isidoro Blikstein e José Paulo Paes. São Paulo: Cultrix, 1969.

MAINGUENEAU, Dominique. Elementos de lingüística para o texto literário. Tradução Maria Augusta de Matos. São Paulo: Martins Fontes, 1996.

PALLOTINI, Renata. Introdução à dramaturgia. São Paulo: Ática, 1988.

PAVIS, Patrice. Dicionário de teatro. Tradução Maria Lúcia Pereira et al. São Paulo: Perspectiva, 1999.

RYNGAERT, Jean Pierre. Introdução à análise do teatro. Tradução Paulo Neves. São Paulo: Martins Fontes, 1995.

SOURIAU, Etienne. As duzentas mil situações dramáticas. Tradução Maria Lúcia Pereira. São Paulo: Ática, 1993.

Recebido: 17 de abril de 2015 Aprovado: 20 de novembro de 2015 Contatos: edsonbog@terra.com.br ducatanozi@terra.com.br 